Aspergillus airway colonization and invasive disease after lung transplantation. Chest 1997;112:1160-1164.

12. Maurer JR, Tullis E, Grossman RF, Vellend H, Winton TL, Patterson GA. Infectious complications following isolated lung transplantation. Chest 1992;101:1056-1059.

13. Westney GE, Kesten S, DeHoyas A, Chapparo C, Winton T, Maurer JR. Aspergillus infection in single and double lung transplant recipients. Transplantation 1996;61:915-919.

14. Yeldandi V, Laghi F, McCabe MA, Larson R, O'Keefe P, Husain A, et al. Aspergillus and lung transplantation. I Heart Lung Transplant 1995; 14:883-890.

15. Hadley S, Karchmer AW. Fungal infections in solid organ transplant recipients. Infect Dis Clin North Am 1995;9:1045-1073.

16. Iwen PC, Reed EC, Armitage JO, Bierman PJ, Kessinger A, Vose JM, et al. Nosocomial invasive aspergillosis in lymphoma patients treated with bone marrow or peripheral stem cell transplants. Infect Control Hosp Epidemiol 1993;14:131-139.

17. Wald A, Leisenring W, van Burik JA, Bowden RA. Epidemiology of Aspergillus infections in a large cohort of patients undergoing bone marrow transplantation. I Infect Dis 1997:175:1459-1466.

18. Peterson PK, McGlave P, Ramsay NK, Rhame F, Cohen E, Perry GS 3rd, et al. A prospective study of infectious diseases following bone marrow transplantation: emergence of Aspergillus and cytomegalovirus as the major causes of mortality. Infect Control 1983;4:81-89.

19. Pannuti CS, Gingrich RD, Pfaller MA, Wenzel RP. Nosocomial pneumonia in adult patients undergoing bone marrow transplantation: a 9-year study. J Clin Oncol 1991;9:77-84.

20. Arnow PM, Andersen RL, Mainous PD, Smith EJ. Pulmonary aspergillosis during hospital renovation. Am Rev Respir Dis 1978;118:49-53.

21. Opal SM, Asp AA, Cannady PB Jr, Morse PL, Burton LJ, Hammer PG 2nd. Efficacy of infection control measures during a nosocomial outbreak of disseminated aspergillosis associated with hospital construction. I Infect Dis 1986;153:634-637.

22. Weems JJ Jr, Davis BJ, Tablan OC, Kaufman L, Martone WJ. Construction activity: an independent risk factor for invasive aspergillosis and zygomycosis in patients with hematologic malignancy. Infect
Control 1987:8:71-75.

23. Iwen PC, Davis JC, Reed EC, Winfield BA, Hinrichs SH. Airborne fungal spore monitoring in a protective environment during hospital construction, and correlation with an outbreak of invasive aspergillosis. Infect Control Hosp Epidemiol 1994;15:303-306.

24. Patterson JE, Zidouh A, Miniter P, Andriole PT, Patterson TF. Hospital epidemiologic surveillance for invasive aspergillosis: patient demographics and the utility of antigen detection. Infect Control Hosp Epidemiol 1997;18:104-108.

25. Loo VG, Bertrans C, Dixon C, Vitye D, Desalis B, McLean AP, et al. Control of construction-associated nosocomial aspergillosis in an antiquated hematology unit. Infect Control Hosp Epidemiol 1996;17:360364 .

26. Mullins J, Harvey R, Seaton A. Sources and incidence of airborne Aspergillus fumigatus (Fres). Clin Allergy 1976;6:209-217.

27. Walsh TJ, Dixon DM. Nosocomial aspergillosis: environmental microbiot ogy, hospital epidemiology, diagnosis and treatment. Eur J Epidemiol 1989;5:131-142.

28. Rhame FS, Streifel AJ, Kersey JH Jr, McGlave PB. Extrinsic risk factors for pneumonia in the patient at high risk for infection. Am J Med $1984 ; 76(5 \mathrm{~A}): 42-52$

29. Rhame FS, Streifel A, Stevens P, et al. Endemic Aspergillus airborne spore levels are a major risk factor for aspergillosis in bone marrow transplant (BMT) patients. Abstracts of the 25th Interscience Conference on Antimicrobial Agents and Chemotherapy; Minneapolis, MN; September 1985. Abstract A147.

30. Hopkins CC, Weber DJ, Rubin RH. Invasive aspergillosis infection: possible non-ward common source within the hospital environment. J Hosp Infect 1989;13:19-25.

31. Gerson SL, Parker P, Jacobs MR, Creger R, Lazarus HM. Aspergillosis due to carpet contamination. Infect Control Hosp Epidemiol 1994;15:221-223.

32. Weber DJ, Rutala WA. Environmental issues and nosocomial infections In: Wenzel RP, ed. Prevention and Control of Nosocomial Infections. 3rd ed. Baltimore, MD: Williams \& Wilkins; 1997:491-514.

33. Centers for Disease Controls and Prevention. Guidelines for prevention of nosoconial pneumonia. MMWR 1997;46(RR-1):1-77.

\title{
Transmission of TB to a Funeral Director During Routine Embalming
}

\section{Gina Pugliese, RN, MS Martin S. Favero, PhD}

Several studies have shown that funeral directors have an increased risk of contracting TB. Although there is indirect evidence of transmission of TB from cadavers to mortuary workers, there is only one recently documented case in the literature. Lauzardo and coinvestigators from the Florida Department of Health in Gainesville report another case of occupationally acquired TB in a funeral director, which was confirmed by conventional epi- demiology and genotyping. The link between the mortician's illness and that of the woman whose body she embalmed was discovered in an investigation of numerous rifampin-monoresistant (RMR) TB cases that occurred in Florida in 1995 and 1996 . The source individual was a 34year-old woman who died in November 1996, after having been treated for TB since June 1995.

The investigators could not discover any links between the two patients other than the embalming. On the basis of a survey at the funeral home, they concluded that the most likely explanation of the dis- ease transmission was that tubercle bacilli became aerosolized during embalming when the source patient's body fluids were siphoned out and drained into a sink. They noted that morticians at the funeral home routinely wore surgical masks and that an exhaust fan used during embalming was normally shut off immediately after the procedure, possibly leaving infectious particles in the air.

FROM: Lauzardo M, Lee P, Duncan H, Hale Y. Transmission of Mycobacterium tuberculosis to a funeral director during routine embalming. Chest 2001;119:640642. 